\title{
Technical and Economic Feasibility of the First Wind Farm on Egypt's Mediterranean Sea Coast
}

Ahmed Shata Ahmed ( $\square$ ahmedshata72@hotmail.com )

Department of Physics, Faculty of Science, Port Said University, Egypt.

Research

Keywords: Sustainable energy, Capacity factor, Wind farm, Egypt

Posted Date: January 4th, 2021

DOl: https://doi.org/10.21203/rs.3.rs-136495/v1

License: (c) (i) This work is licensed under a Creative Commons Attribution 4.0 International License. Read Full License 


\title{
Technical and economic feasibility of the first wind farm on Egypt's Mediterranean Sea coast
}

\author{
Ahmed Shata Ahmed \\ Department of Physics, Faculty of Science, Port Said University, Egypt.
}

\begin{abstract}
Recently, the utilization of wind turbines in the production of clean energy has been increased to achieve sustainable electricity supply, as planned by the government of Egypt through the use of renewable resources like wind power. This paper purposed to assess the wind power potential for the coastal area in Sidi Barrani province, a meteorological station with mast of $10 \mathrm{~m}$ was constructed near the Mediterranean Sea shore in Egypt. The density of wind power was assessed at the level of $100 \mathrm{~m}$ monthly and seasonally after taking into account the correction of air density. On the annual basis, the station is rated with high potential $441 \mathrm{~kW} / \mathrm{m}^{2}$. This is an ideal location for large-scale wind turbine to generate sustainable electricity. A performance assessment was executed using three commercialized wind generators having capacity of 2000 $\mathrm{kW}$ from different manufacturers and were also equal in height and rotor diameter, for choosing the best unit suitable for the target area. The economic analysis of a $200 \mathrm{MW}$ coastal wind farm in the studied area was done using the advanced method of present value costs. The findings prove that the proposed project could produce approximately $988 \mathrm{GWh}$ per year of electrical energy with an economic price of 1.7 US cents per $k W h$. Consequently, this huge sustainable electrical energy produced from this project can be transferred to Southern European countries along the Mediterranean, because it is relatively more than the Egypt's needs. It also limits the burning of local petroleum products, as well as stopping the emission of thousands of tons of carbon annually.
\end{abstract}

Keywords: Sustainable energy; Capacity factor; Wind farm; Egypt.

E-mail address: ahmedshata72@hotmail.com

\section{Introduction}

Wind energy is used to generate electricity by converting the movement energy present in the wind into an electrical energy, as it is seen as a mature technology. In locations with high wind speeds, the cost of production is economical and competitive with traditional energy technologies, especially when taking into account environmental impacts and calculating fuel prices used in thermal plants at market price (without government support). On the other hand, because of the drooping in wind turbine costs, and increase air pollution in the atmosphere as a result of burning fossil fuels in many countries all over the world. The establishment and growth of wind power plants has become one of the most important strategic goals of any developing country, such as Arab Republic of Egypt, which owns sufficient renewable energy potential to maintain its energy needs and help economic development in the coastal desert areas bordering the Mediterranean Sea and the Red Sea.

For valid and efficient use of wind energy, knowledge of the statistical properties and forecasting of wind speed is very important to judge the wind resource. This information is necessary for site 
selection, performance forecast, and optimal layout for wind farms. Prior studies have focused during the past five years on examining the potential of wind energy and its suitability for the installation of wind farms in various parts of the Middle East region such as Turkey [1], Iran [2], Kuwait [3] and Saudi Arabia [4]. In addition to some literatures have been presented on Morocoo [5], Algeria [6], Libya [7], and the Republic of Djibouti [8]. While little has been carried out in scientific research related to the use of wind energy to generate electricity in Egypt, for an example [9-13].

Based on the author's survey of works published in a number of leading scientific journals in the energy field over the past decade, no research has been done on sitting up large wind farms to generate electricity, as well as the cost of producing the sustainable energy per $\mathrm{kWh}$ from the wind in the northwestern of Arab Republic of Egypt along the coast of Mediterranean Sea. Therefore, the main objective of the submitted work is to study the techno-economic viability of establishing the first 200 MW inshore wind farm to generate wind power in the coastal area of Sidi Barrani located on Mediterranean Sea shores in Egypt.

\section{Description of coastal station}

The Sidi Barrani mast is situated a few kilometers NW of the town of Sidi Barrani. The shortest distance to the coastline of the Mediterranean Sea is a few hundred meters in a northerly direction. The coastline is rocky and consists of a small cliff or escarpment. There are a few low sheltering obstacles (the meteorology station buildings) S and SE of the mast. The surface consists mostly of rocks and bare soil with a roughness length of about or less than $0.01 \mathrm{~m}$. In this essay, the mean monthly wind speed data for more than ten years (1995-2014) are utilized. The measured data is taken at a height of 10 meters above the ground level, which were registered by the Meteorological Agency in Cairo along with the Egyptian Renewable Energy Authority. Target area (Sidi Barrani) and geographical information for the coastal location are identified in Fig. 1 and Table 1, respectively.

Table 1

Geographical coordinates of the studied location and wind properties.

\begin{tabular}{|c|c|c|c|c|c|c|c|c|}
\hline Station & Latitude & Longitude & Altitude & Anemometer & Wind Shear & \multicolumn{2}{|c|}{ Annual mean wind speed (m/s) } \\
\cline { 5 - 8 } & degree & Wegree & $m$ & height $(\mathrm{m})$ & Coefficient $(\alpha)$ & at $10 \mathrm{~m}$ & at $100 \mathrm{~m}$ & \\
\hline Sidi Barrani & $31^{0} 37$ & $25^{0} 54$ & 2 & 10 & 0.21 & 6.1 & 9.9 & $330 \mathrm{NW}$ \\
\hline
\end{tabular}




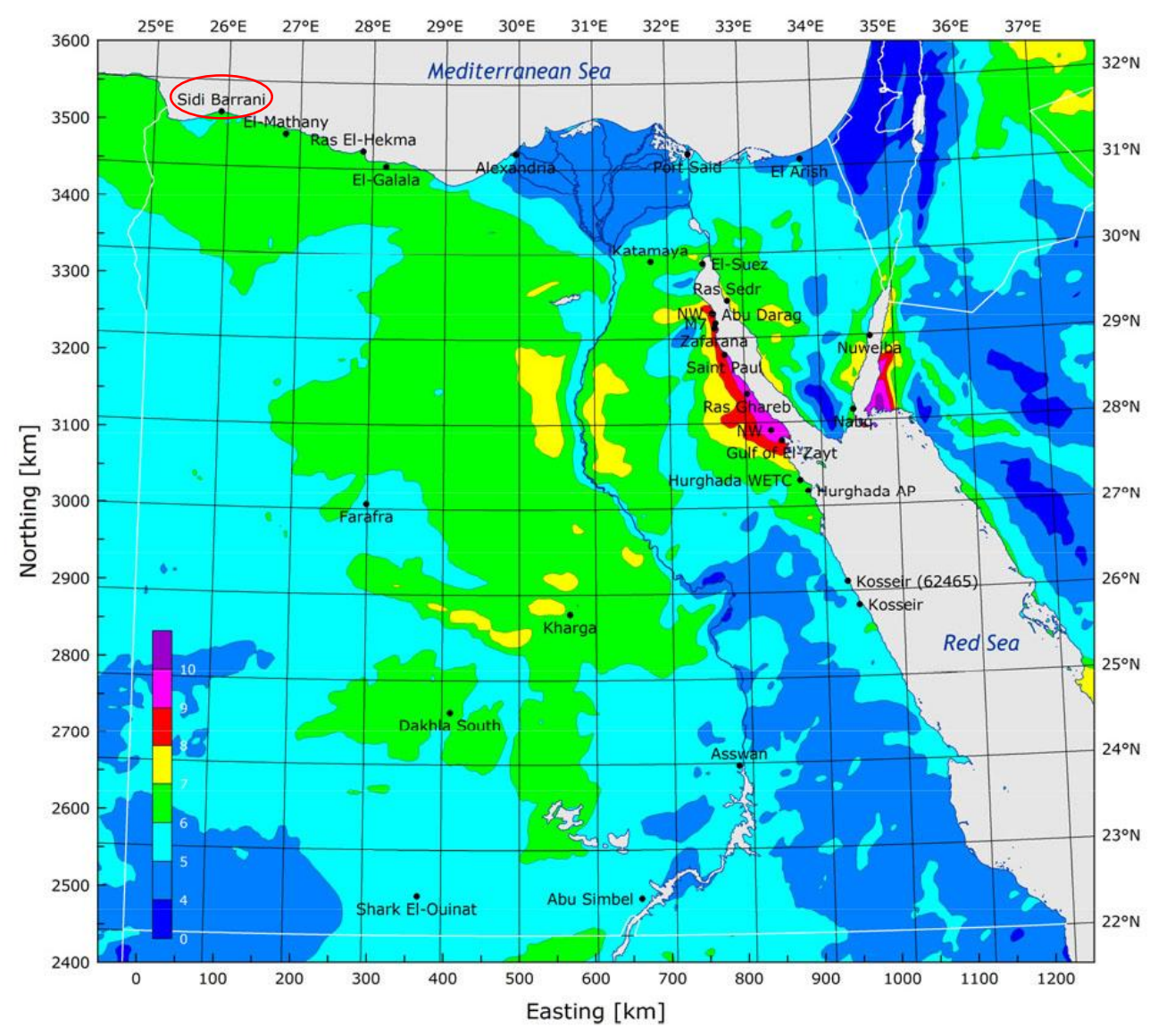

Fig. 1. Location of Sidi Barrani meteorological station along Mediterranean Sea in Egypt. (Source: New wind resource map of Egypt at a height of $50 \mathrm{~m}$ over the actual land surface [41])

\section{Method of analysis}

To get the correct value of the wind energy density at various altitudes, the wind shear coefficient $\boldsymbol{\alpha}$ must be firstly evaluated for the chosen area [14]. This factor could be obtained through the advanced formula:

$$
\alpha=0.37-0.0881 \ln V_{10}
$$

where $V_{10}$ is the measured wind speed at the standard elevation $10 \mathrm{~m}$ above sea level. 
The density $\rho$ of the air varies with altitude and with the atmospheric conditions. This is important because most wind machine power and energy outputs are computed for sea level air density, where the typical value for air density at sea level is $1.225 \mathrm{~kg} / \mathrm{m}^{3}$. In addition, a slight change in the density of air can lead to a significant change in the expected wind power value of the studied site. The correct value of air density per month is determined by the following relation [15-17]:

$$
\bar{\rho}=\frac{\overline{\mathrm{P}}}{\mathrm{R}_{\mathrm{d}} \overline{\mathrm{T}}} \quad\left(\mathrm{kg} / \mathrm{m}^{3}\right)
$$

where, $\overline{\mathrm{P}}$ is the average of air pressure per month in Pascal $\left(\mathrm{N} / \mathrm{m}^{2}\right), \mathrm{R}_{\mathrm{d}}$ is the gas constant for dry air that equals $287 \mathrm{~J} / \mathrm{kg}{ }^{\circ} \mathrm{K}$, and $\overline{\mathrm{T}}$ is the average of air temperature per month in Kelvin Scale $\left({ }^{\circ} \mathrm{C}+273\right)$.

Commonly, power is the rate at which energy is extracted, harnessed, converted or consumed. Thus, the mean wind power -which may be available at $10 \mathrm{~m}$ height from the kinetic energy in the wind across each $1 \mathrm{~m}^{2}$ - can be calculated by the famous expression [18]:

$$
\mathrm{P}_{10}=0.5 \bar{\rho} V_{10}{ }^{3} \quad\left(\mathrm{~W} / \mathrm{m}^{2}\right)
$$

According to Ahmed and Hanitsch [19], to cater for an elevation up to $100 \mathrm{~m}$ above earth's surface, the average monthly of available power can be evaluated as follows:

$$
\mathrm{P}_{\mathrm{h}}=0.36 \bar{\rho} V_{10}{ }^{3}\left(\frac{\mathrm{h}}{10}\right)^{3 \alpha} \quad\left(\mathrm{kW} / \mathrm{m}^{2} . \text { month }\right)
$$

where $\mathrm{h}$ is the desired altitude for the anemometer from 0 to $100 \mathrm{~m}$ at the investigated station.

The monthly capacity factor $\left(\boldsymbol{C F}_{\boldsymbol{m o}}\right)$ must be taken into consideration as the first step towards the final design of the wind farm, the size of the proposed wind machine that will be worked at the specified site must be verified by the relationship [10]:

$$
\boldsymbol{C F}_{\text {mo. }}(\%)=\frac{\mathbf{P}_{\mathrm{a}}}{\mathbf{P}_{\mathbf{r}}} \times 100
$$

where, $\mathrm{P}_{\mathrm{a}}$ is the available power per month for the area under study,

$\mathrm{P}_{\mathrm{r}}$ is the rated power in $\mathrm{kW}$ for the commercialized wind turbine. 


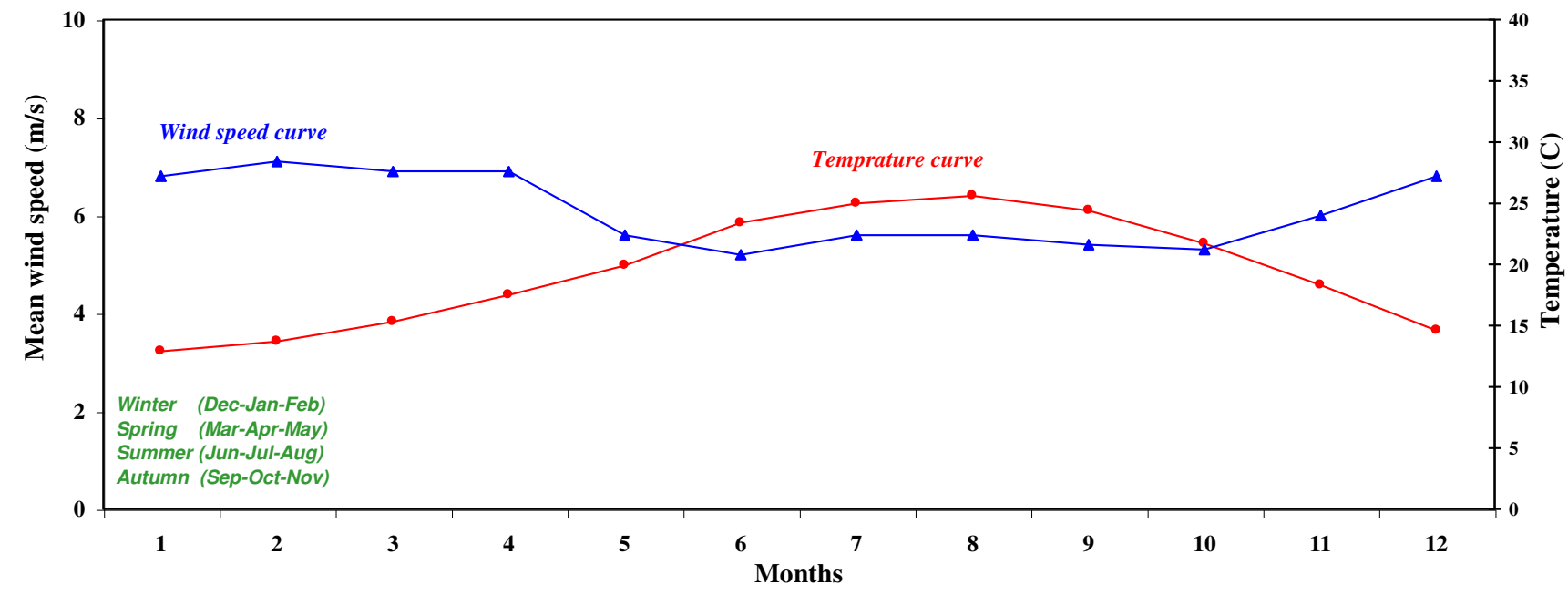

Fig. 2. Variation of mean wind speed and air temperature recorded per month for Sidi Barrani station.

\section{Results and Discussions}

\subsection{Analysis of wind characteristics}

Any venture to set up a wind power plant demands the knowledge of two items: the location and wind. The site relies on the power of the wind and its yearly and seasonal constancy achieved by the analysis of a long-term record. Moreover, wind properties are essential for estimating wind energy on the location. Fig. 2 shows the average monthly of air temperature and wind speeds at $10 \mathrm{~m}$ altitude. After comparing the two curves, the following is observed:

(1) Sidi Barrani's wind climate is characterized by the trade winds with high level in Winter and Spring seasons, whereas in Summer and Autumn months notably reduces due to the apparent increase in air temperature during these months.

(2) As reported by Mostafaeipour et al. [20], the air density increases with the decrease in site temperature. In past sketch and the fourth column of Table 2, we can see this relatively high density in Winter and Spring months, and the monthly wind speeds are higher at these periods.

(3) Again, the diagram proves that the wind speeds peaks are correlated to the values of air temperature that have decreases in different months or seasons over the year. The highest monthly value for wind was $7.1 \mathrm{~m} / \mathrm{s}$ at $10 \mathrm{~m}$ elevation during February. Air temperature was a minimum value $12.9^{\circ} \mathrm{C}$ in January (Winter months).

As a rule, taking a closer look at the wind rose is very helpful in installing and ideal operation of the wind turbines. Where the wind rose gives the frequencies distribution of wind speed and wind direction in form of polar diagrams [14]. For the studied area, the wind direction was measured at $10 \mathrm{~m}$ above ground level. Yearly wind rose is plotted in Fig. 3, based on the recorded data. One can infer that: 
(1) The wind is always more dense and persistent in the direction of $330^{\circ}$. Since the most probable wind direction was among $300^{\circ}$ and $360^{\circ}$, i.e. northwestern winds. Whilst the wind frequency seems to be very low in the rest of the other trends. i.e. at the domain from $30^{\circ}$ to $270^{\circ}$.

(2) Precisely, the most effective frequencies blowing from the sector $330^{\circ}$ were $25.1 \%$ override 7.1 $\mathrm{m} / \mathrm{s}$ at elevation $10 \mathrm{~m}$. The second direction from which the wind arrives highly was $300^{\circ}$, where $15.7 \%$ of hours possess mean wind speed above $7.7 \mathrm{~m} / \mathrm{s}$, followed by strong winds of 6 $\mathrm{m} / \mathrm{s}$ coming from a north sector $\left(360^{\circ}\right)$, with a frequency value of $13.4 \%$ during the entire year.

(3) As a result, winds of this coastal site will remain between from $6-7.7 \mathrm{~m} / \mathrm{s}$, approximately $54 \%$ of the time during the year, and own perfect quality for installing wind parks to electric energy generation. Also, NNW sector is becoming the optimal direction for power generation by wind turbines and should be taken into consideration when building a wind farm at Sidi Barrani.

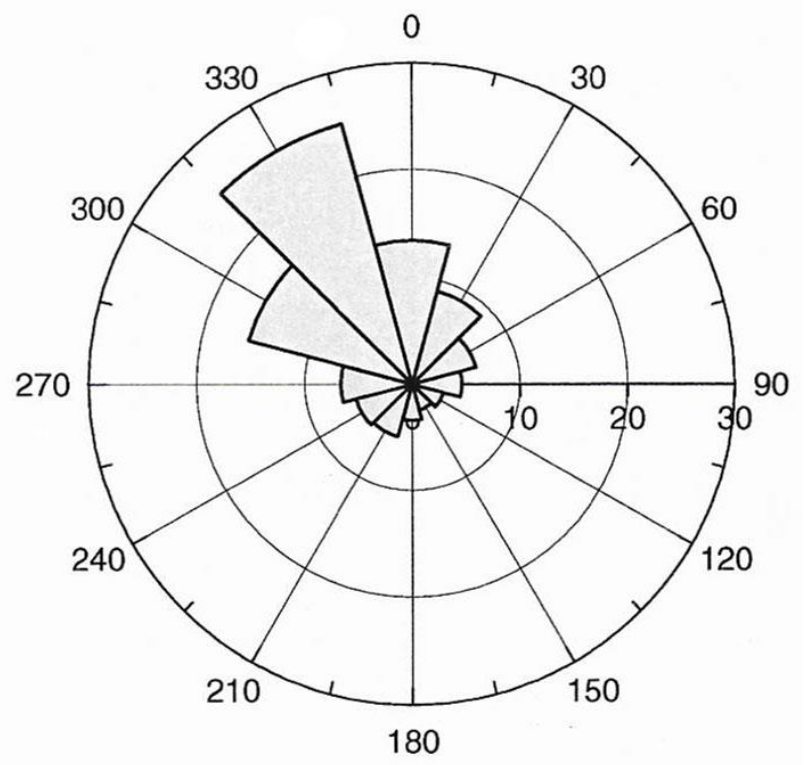

Fig. 3. Yearly wind rose diagram for studied location at $10 \mathrm{~m}$ height.

\subsection{Assessment of air density and wind power potential}

In recent years, an increasing number of studies incorporate the effects of air density changes in the estimation of the wind power density, some are in the Middle East region and its coastal regions e.g. [21-23]. On the other side with regard to Egypt, it is not desirable to assess the values of wind power density by employing a Weibull model, which has been confirmed by many investigators [24-26]. 
Accordingly, the corrected monthly values of air density $\bar{\rho}$ and the available wind power were computed at $100 \mathrm{~m}$ elevation, by utilizing the measured data per month of air temperature and air pressure with Eqs. $(2 \& 4)$, as listed in the fourth and fifth column in Table 2. Hence, there is a slight variation in air density from the typical value. i.e. High-altitude air tends to be thinner. After taking into account changes in air density over the year in power accounts, and we can affirm that:

(1) The weather is stable in the coastal area of Sidi Barrani throughout the year. This is confirmed by a very slight decrease of $\bar{\rho}$ from the standard value of air density, i.e. $1.225 \mathrm{~kg} / \mathrm{m}^{3}$.

(2) At $100 \mathrm{~m}$ altitude, the highest value of wind power density was achieved in February, $\mathbf{P}_{\mathbf{1 0 0}}=$ $682 \mathrm{~kW} / \mathrm{m}^{2}$, while the minimum value was recorded in June, $\mathbf{P}_{100}=257 \mathrm{~kW} / \mathrm{m}^{2}$. On the seasonal scale as illustrated in Fig. 4, the wind power density available at Summer period is the lowest value $893 \mathrm{~kW} / \mathrm{m}^{2}$, and it increases slightly in Autumn season, achieving $967 \mathrm{~kW} / \mathrm{m}^{2}$. The peak value of wind power density was observed during Winter months with $1875 \mathrm{~kW} / \mathrm{m}^{2}$, followed by $1561 \mathrm{~kW} / \mathrm{m}^{2}$ in Spring season.

(3) These values are globally ideal and close to the levels of wind energy density in many European cities, and could generate electricity in a sustainable manner by the wind, like Galicia (Spain).

\section{Table 2}

Monthly values of mean wind speed, air temperature and atmospheric pressure observed at elevation $10 \mathrm{~m}$ on sea level, respectively [41,42], beside the corrected air density, estimated wind power available at $100 \mathrm{~m}$ and capacity factor for Sidi Barrani station.

\begin{tabular}{|c|c|c|c|c|c|c|}
\hline Month & $\begin{array}{c}V_{10} \\
(\mathrm{~m} / \mathrm{s})\end{array}$ & $\begin{array}{c}T \\
\left({ }^{0} \mathrm{C}\right)\end{array}$ & $\begin{array}{c}\boldsymbol{P} \\
\left(\mathrm{x} 10^{2} \mathrm{~N} / \mathrm{m}^{2}\right)\end{array}$ & $\begin{array}{c}\bar{\rho} \\
\left(\mathrm{kg} / \mathrm{m}^{3}\right)\end{array}$ & $\begin{array}{c}\boldsymbol{P}_{100} \\
\left(\mathrm{~kW} / \mathrm{m}^{2}\right)\end{array}$ & $\begin{array}{c}C F_{m o} \\
\%\end{array}$ \\
\hline Jan. & 6.8 & 12.9 & 1016.8 & 1.24 & 599 & 30.0 \\
\hline Feb. & 7.1 & 13.7 & 1016.1 & 1.24 & 682 & 34.1 \\
\hline Mar. & 6.9 & 15.3 & 1014.6 & 1.23 & 620 & 31.0 \\
\hline Apr. & 6.9 & 17.5 & 1013.3 & 1.22 & 615 & 30.8 \\
\hline May. & 5.6 & 19.9 & 1013.3 & 1.21 & 326 & 16.3 \\
\hline Jun. & 5.2 & 23.4 & 1012.3 & 1.19 & 257 & 12.9 \\
\hline Jul. & 5.6 & 25.0 & 1010.0 & 1.18 & 318 & 15.9 \\
\hline Aug. & 5.6 & 25.6 & 1009.6 & 1.18 & 318 & 15.9 \\
\hline Sep. & 5.4 & 24.4 & 1013.3 & 1.19 & 288 & 14.4 \\
\hline Oct. & 5.3 & 21.7 & 1015.6 & 1.20 & 274 & 13.7 \\
\hline Nov. & 6.0 & 18.3 & 1017.4 & 1.22 & 405 & 20.3 \\
\hline Dec. & 6.8 & 14.6 & 1017.3 & 1.23 & 594 & 29.7 \\
\hline Annual & 6.1 & 19.4 & 1014.1 & 1.21 & 441 & 22.1 \\
\hline
\end{tabular}




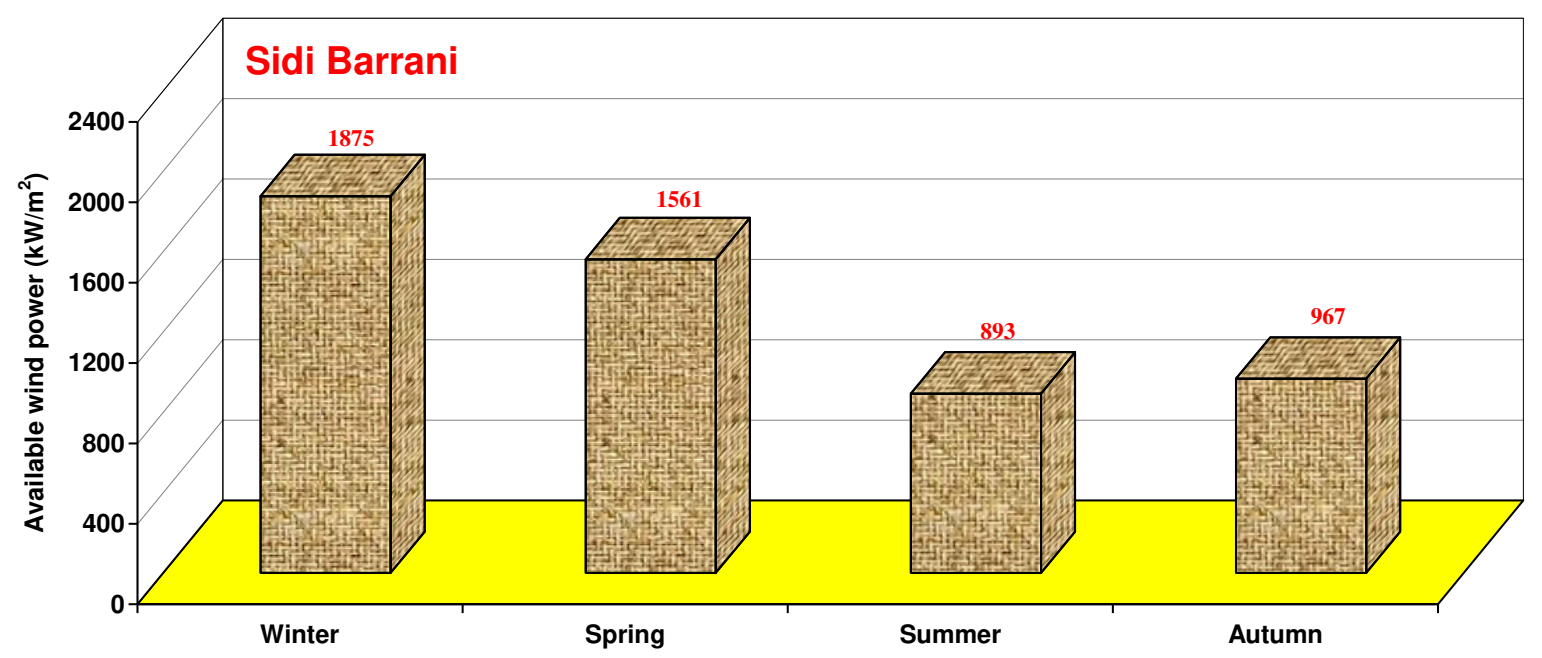

Fig. 4. Seasonally values of wind power potential for hub height of $100 \mathrm{~m}$.

\subsection{Wind turbine productivity to select the best fit}

Capacity factor per year or per month is an important index for evaluating the field performance of a wind turbine (i.e. the productivity of the wind machine). It is a critical criterion for choosing the appropriate wind turbine for the investigated area before discussing the economic feasibility of a wind energy plant [27]. As assured by Ahmed and Hanitsch [28], a wind turbine generator of $2 \mathrm{MW}$ capacity and $100 \mathrm{~m}$ axis height is convenient for working in the town of Sidi Barrani to generate electricity, that based on the results of examining Weibull parameters for the mentioned site. In order to confirm suitability of the wind machine capacity of 2 MW for the coastal area under study, we assume a 2 MW wind machine installed with $100 \mathrm{~m}$ height above earth's surface. Then, for estimating the capacity factor of this turbine, we employing the obtained data, $\mathbf{P}_{\mathbf{1 0 0}}$, -which given in the fifth column of Table 2- with Equation (5). The outcomes are outlined in the last column of Table 2, we can derive that:

(1) The obtained monthly values for the capacity factor tend to be distributed on an optimum range and extending from $12.9 \%$ until $34.1 \%$ on year-round. This is a positive indicator that the putative wind turbine will run most of the time throughout the year -as stated by Kumar and Prasad [29]- for wind power generation at the specified location.

(2) Having known the average annual of $\boldsymbol{C F} \%$ for the proposed turbine is $22.1 \%$, the full load hours factor of this turbine -which means the correlation between the wind turbine operation time and its nominal potential- can be estimated by applying the equation presented by Lima and Filho [30] and referred by Djamai and Merzouk [31]. So, the aforesaid generator will achieve a total of $1935 \boldsymbol{h}$ of operative yearly hours. 
(3) The main conclusion drawn from this examination and the foregoing is that: it is possible to design an inshore wind farm using $2 \mathrm{MW}$ size commercial wind turbines of $100 \mathrm{~m}$ hub height and can be operated in the target area on the Mediterranean coast.

The next step, to install the right turbine at the right location, a performance assessment of three German-made wind turbines from different manufacturers with equal capacities of 2 MW was taken [32-34]. Which are equal in the rotor diameter $=100 \mathrm{~m}$ and have the same hub height $100 \mathrm{~m}$. Technical specifications of the wind generators are recapitulated in Table 3. In terms of practical application (i.e. on the perspective of the annual production of the wind turbine to select the best fit), the energy yield has been estimated in the year after using the wind data of the coastal station with the $\boldsymbol{W} \boldsymbol{A}^{S} \boldsymbol{P}$ software program. The results are listed for the three units in the last row of Table 3 and drawn as curves in Fig. 5. Curves of FWT 2000, W2E-100/2.0 and Senvion MM100 show the annual amount of electrical energy produced by every wind instrument, which amounting to 9,771 $M W h, 9,774 M W h$, and 9,883 $M W h$, in order.

It can be noted that Senvion MM100 is the most efficient unit among the proposed wind turbines with a total energy yield 9,883 $M W h$ per year. This can be explained to give a clear picture for the decisionmakers and planners of wind energy projects as follows:

(1) Firstly, the annual energy yield by the turbine Senvion MM100 is relatively larger than the energy produced from the commercialized turbines $\boldsymbol{F W T} 2000$, and $\boldsymbol{W} 2 \boldsymbol{E}-\mathbf{1 0 0 / 2 . 0}$. This is caused by the cut-in speed is $3 \mathrm{~m} / \mathrm{s}$ for Senvion $\mathbf{M M 1 0 0}$ whilst for other units $3.5 \mathrm{~m} / \mathrm{s}$. Since the electric power from the wind turbine is ruled by the design characteristics such as cut-in speed, which is the minimum limit of wind speed required to begin delivering advantageous energy [35].

(2) Secondly, the commercial turbine Senvion MM100 has lower rated speed $11 \mathrm{~m} / \mathrm{s}$, competitive with rest other turbines, see Table 3. This makes the wind generator produces more energy. Because of the use of a wind machine with lower rated speed would generate more energy yield during the year than a wind machine with greater rated speed [36].

(3) Likewise, if 100 turbines are collected as an example from every class to participate in a 200 MW wind power project, the expected energy yield difference between Senvion MM100 and $(\boldsymbol{F W T} 2000 \& \boldsymbol{W} \mathbf{E}-\mathbf{1 0 0 / 2 . 0})$ as a wind farm is approximately $11 \boldsymbol{G W h}$ per year.

(4) Hence, we recommend choosing the Senvion MM100 turbine model of $100 \mathrm{~m}$ hub height -as the best wind energy generator at the level of $2 \mathrm{MW}$ capacity (current study)- for setting up a wind farm with $200 \mathrm{MW}$ total power in the coastal area of Sidi Barrani. 
Table 3

Technical details of three different wind turbines [32-34] and the yearly energy output calculated by $\mathrm{WA}^{\mathrm{S}} \mathrm{P}$ for the studied area.

\begin{tabular}{|l|c|c|c|}
\hline Wind machine & W2E-100/2.0 & FWT 2000 & Senvion MM 100 \\
\hline Wind class & IEC 3a & IEC 3a & IEC IIA \\
Manufacturer & Germany & Germany & 2 MW W \\
Rated Power & 2 MW & 2 MW & 100 \\
Hub height $(\mathrm{m})$ & 100 & 100 & 100 \\
Rotor diameter $(\mathrm{m})$ & 100 & 100 & 7854 \\
Swept area $\left(\mathrm{m}^{2}\right)$ & 7854 & 7854 & 3 \\
Cut-in wind speed $(\mathrm{m} / \mathrm{s})$ & 3.5 & 3.5 & 11 \\
Rated wind speed $(\mathrm{m} / \mathrm{s})$ & 11.5 & 11.5 & 22 \\
Cut-off wind speed $(\mathrm{m} / \mathrm{s})$ & 25 & 25 & 20 \\
Epected life $(\mathrm{years})$ & 20 & 20 & $2,500,000$ \\
Price / US \$ & -- & $9,774,894$ & $9,883,123$ \\
E out $(\mathrm{kWh} / \mathrm{year})$ & $9,771,293$ & & \\
\hline
\end{tabular}

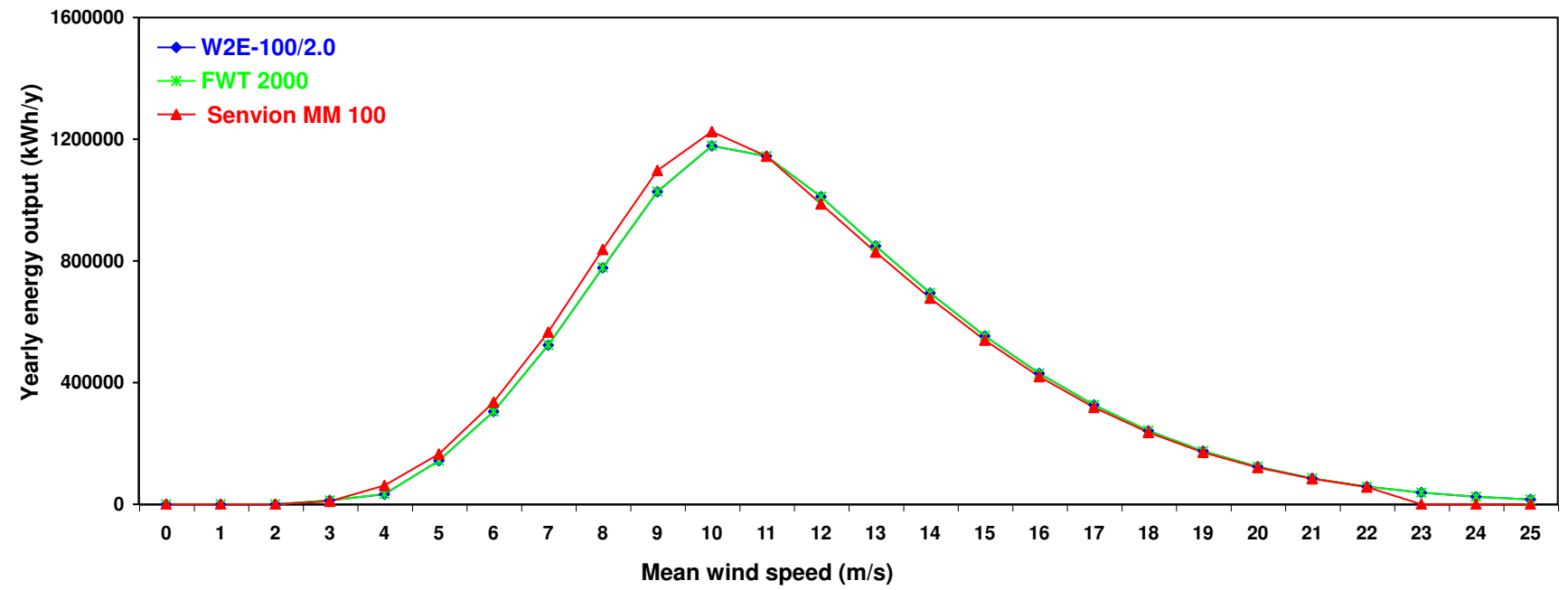

Fig. 5. The average annual energy yield by three various wind turbines considered at the selected area. 


\subsection{Economic analysis of a 200 MW coastal wind farm}

In this partition, the economic feasibility of the proposed inshore wind farm to be established on the Mediterranean coast in Egypt will be examined. The putative wind farm has a capacity of 200 MW (100 turbines of capacity of 2 MW each). The cost of a commercialized wind turbine Senvion MM100 and its technical characteristics are mostly determined by the German manufacturer as listed in Table 3. At Sidi Barrani station, the predominating wind is mainly blowing from the sector $330^{\circ}$ and is ideally suited for wind units installed in the wind energy plant.

Because a complete economic analysis of wind energy versus other energy options requires an estimate of all costs incurred over the life of the wind system. The technique of present value costs (PVC) was recently performed by several authors to access the specified cost of each $\mathrm{kWh}$ of electrical energy generated by wind turbines [37-39]. This technique was advanced by Ahmed [40] (if the number of units in the proposed wind farm is equal to 100 or more turbines), and will be applied in the current work with the following presumptions [10]:

$$
\mathbf{P V C}=\boldsymbol{I}+\boldsymbol{M H}+\boldsymbol{C}_{o m r}\left[\frac{1+\mathbf{i}}{\mathbf{r}-\mathbf{i}}\right] \times\left[1-\left(\frac{1+\mathbf{i}}{\mathbf{1}+\mathbf{r}}\right)^{\mathbf{t}}\right]-\mathbf{S}\left(\frac{1+\mathbf{i}}{\mathbf{1}+\mathbf{r}}\right)^{\mathbf{t}}
$$

where

-The investment $\boldsymbol{I}$ involves the wind turbine price plus its $20 \%$ for the civil work and other connections.

- The major overhaul $\boldsymbol{M H}$ is a fixed value of $2 \%$ from $\boldsymbol{I}$.

- The scrap value $\mathbf{S}$ is taken as $10 \%$ from $\boldsymbol{I}$.

- The repair cost $\boldsymbol{C}_{\boldsymbol{o m} r}$ includes the maintenance \& operation and is computed by $25 \%$ of the yearly cost of the wind unit (turbine price/duration of life).

- Based on the Egyptian context, the interest rate $\mathbf{r}$ is $15 \%$ and the inflation rate $\mathbf{i}$ is $12 \%$.

- The shelf life of the wind turbine designed by the manufacturer $\mathbf{t}$ is 20 years.

To calculate the projected cost of each $\mathrm{kWh}$ of electricity produced by the suggested wind plant. First, the capital investment, $\boldsymbol{I}$, is taken as the number of units multiplied by the unit price. Thus, after replacing all the former factors in the Equation (6), the value of PVC was estimated to be:

$$
\text { PVC }=336,217,056
$$


Next, the calculated energy output for 100 turbines with a total installed capacity of 200 MW was approximately 988,312,300 $\mathrm{kWh}$ per year, as shown in Table 4. Therefore, the expected cost per $\mathrm{kWh}=$ $[(336,217,056) /(20 \times 988,312,300)]=1.7$ US cent .

Table 4

Annual energy output, capacity factor, full load hours factor and specific cost per $\mathrm{kWh}$, respectively, for the $200 \mathrm{MW}$ wind farm at the coastal area of Sidi Barrani, Egypt.

\begin{tabular}{|c|c|c|c|c|}
\hline Station & $\begin{array}{c}E_{\text {out }} \\
(\mathrm{kWh} / \text { year })\end{array}$ & $\begin{array}{c}\text { CF yealy } \\
(\%)\end{array}$ & $\begin{array}{c}\text { FLH } \\
(\text { hour/year })\end{array}$ & $\begin{array}{c}\text { Cost } \\
(\text { US cent/kWh })\end{array}$ \\
\hline Sidi Barrani & $988,312,300$ & 56 & 4,905 & 1.7 \\
\hline
\end{tabular}

Also from Table 4, the yearly capacity factor for the considered wind farm is high 56\%, which represents about 4905 of operative yearly hours. The obtained full load hours are greater than those values for the best working wind farms in Spain, that operate annually between (2830-3000) hours of real generation, as already mentioned in Ref. [10]. Thus, the installation of a wind farm at this coastal location to generate electricity is economically and technically feasible.

\section{Conclusions}

The Arab Republic of Egypt is from one of the Red Sea and Mediterranean Sea nations that have enough wind stormy regions, especially along marine coasts. In short, wind power in Egypt is indigenous and environmentally friendly. Since the Egyptian government pays millions of dollars every year to import the rest of its oil and gas needs, and most of it is used to generate electricity. Developing this source and using it to generate clean electricity will reduce the pressure on oil imports, improve the social and economic conditions for the Egyptian people, and protect the environment from pollution. So, the government of Egypt should make concerted efforts to spread wind farms in the country's coastal areas.

From all the preceding, the outcomes of this work have clearly confirmed that the proposed wind farm of 200 MW installed capacity -in the coastal area of Sidi Barrani, Egypt- is possible technically and economically feasible and demands due attention from officials and investors. Moreover, this project will decrease the burning of hundreds of tons of fossil fuels to produce electricity in Egypt, thereby reducing Greenhouse Gas Emissions (GHG) in the regional climate. 


\section{Declarations}

\section{Acknowledgements}

Not applicable.

\section{Author's contributions}

The author read and approved the final manuscript.

\section{Funding}

Not applicable.

\section{Availability of data and materials}

All data generated or analyzed during this study are of my own work and it is my pleasure to be available publically.

\section{Competing interests}

The author declares that he has no competing interests.

\section{References}

[1] Arslan H, Baltaci H, Akkoyunlu BO, Karanfil S, Tayanc M. Wind speed variability and wind power potential over Turkey: Case studies for Çanakkale and İstanbul. Renewable Energy 2020;145:1020-1032.

[2] Pishgar-Komleh SH, Akram A. Evaluation of wind energy potential for different turbine models based on the wind speed data of Zabol region, Iran. Sustainable Energy Technologies and Assessments 2017;22: 34-40.

[3] Alkhalidi MA, Al-Dabbous SK, Neelamani S, Aldashti HA. Wind energy potential at coastal and offshore locations in the state of Kuwait. Renewable Energy 2018;1135:529-539.

[4] Rafique MM, Rehman S, Alam MM, Alhems LM. Feasibility of a 100 MW Installed Capacity Wind Farm for Different Climatic Conditions. Energies 2018;11:2174.

[5] Nouri A, Babram MA, Elwarraki E, Enzili M. Moroccan wind farm potential feasibility. Case study. Energy Conversion and Management 2016;122:39-51.

[6] Boudia SM, Santos JA. Assessment of large-scale wind resource features in Algeria. Energy 2019;189:116299.

[7] Kassem Y, Gökçekuş H, Faraj RA. Evaluation of the Wind Energy Potential in Libya's Eastern Mediterranean Coast Area Using Weibull Distribution Function. International Journal of Applied Engineering Research 2019;14(10):2483 -2491 .

[8] Idriss AI, Ahmed RA, Omar AI, Said RK, Akinci TC. Wind energy potential and micro-turbine performance analysis in Djibouti-city, Djibouti. Engineering Science and Technology, an International Journal 2020;23:65-70. 
[9] Amin I, Ali MEA, Bayoumi S, Oterkus S, Shawky H, Oterkus E. Conceptual Design and Numerical Analysis of a Novel Floating Desalination Plant Powered by Marine Renewable Energy for Egypt. Journal of Marine Science and Engineering 2020;8:95.

[10] Ahmed AS. Analysis the economics of sustainable electricity by wind and its future perspective. Journal of Cleaner Production 2019;224:729-738.

[11] Moness M, Moustafa AM. A critical review of research trends for wind energy in Egypt: recent progress and promising opportunities. Int. J. Energy Technology and Policy 2019;15:31-70.

[12] Ahmed AS. Wind energy characteristics and wind park installation in Shark El-Ouinat, Egypt. Renewable and Sustainable Energy Reviews 2018;82:734-742.

[13] Shouman ER. International and national renewable energy for electricity with optimal cost effective for electricity in Egypt. Renewable and Sustainable Energy Reviews 2017;77:916-923.

[14] Hulio ZH, Jiang W, Rehman S. Techno - Economic assessment of wind power potential of Hawke's Bay using Weibull parameter: A review. Energy Strategy Reviews 2019;26:100375.

[15] Mathaba T, Mpholo M, Letuma M. Velocity and power density analysis of the wind at Letšeng-la-terae in Lesotho. Renewable Energy 2012;46:210-217.

[16] Keyhani A, Ghasemi-Varnamkhasti M, Khanali M, Abbaszadeh R. An assessment of wind energy potential as a power generation source in the capital of Iran, Tehran. Energy 2010;35:188-201.

[17] Ahmed SAS, Hanitsch R. Evaluation of wind energy potential and electricity generation on the coast of Mediterranean Sea in Egypt. Renewable Energy 2006;31:1183-1202.

[18] Ahmed AS. Wind resource assessment and economics of electric generation at four locations in Sinai Peninsula, Egypt. Journal of Cleaner Production 2018;183:1170-1183.

[19] Ahmed SAS, Hanitsch R. Electricity generation and wind potential assessment at Hurghada, Egypt. Renewable Energy 2008;33:141-148.

[20] Mostafaeipour A, Sedaghat A, Dehghan-Niri AA, Kalantar V. Wind energy feasibility study for city of Shahrbabak in Iran. Renewable and Sustainable Energy Reviews 2011;15:2545-2556.

[21] Laiola E, Giungato P. Wind characterization in Taranto city as a basis for innovative sustainable urban development. Journal of Cleaner Production 2018;172:3535-3545

[22] Baseer MA, Meyer JP, Rehman S, Alam MM. Wind power characteristics of seven data collection sites in Jubail, Saudi Arabia using Weibull parameters. Renewable Energy 2017;102:35-49.

[23] Nedaei M, Assareh E, Biglari M. An extensive evaluation of wind resource using new methods and strategies for development and utilizing wind power in Mah-shahr station in Iran. Energy Conversion and Management 2014;81: 475-503.

[24] Lashin A, Ahmed S. An analysis of wind power potential in Port Said, Egypt. Renewable and Sustainable Energy Reviews 2012;16:6660-6667.

[25] Ahmed ASA, Hanitsch R. The potential of electricity generation on the east coast of Red Sea in Egypt. Renewable Energy 2006;31:1597-1615.

[26] Mayhoub AB, Azzam A. A survey on the assessment of wind energy potential in Egypt. Renewable Energy 1997;11 (2):235-247.

[27] Hulio ZH, Jiang W, Rehman S. Technical and economic assessment of wind power potential of Nooriabad, Pakistan. Energy, Sustainability and Society 2017;7:35.

[28] Ahmed ASA, Hanitsch R. Applications of electricity generation on the western coast of the Mediterranean Sea in Egypt. International Journal of Ambient Energy 2008; 29(1):35-44.

[29] Kumar A, Prasad S. Examining wind quality and wind power prospects on Fiji Islands. Renewable Energy 2010;35: $536-540$.

[30] Lima LDA, Filho CRB. Wind energy assessment and wind farm simulation in Triunfo - Pernambuco, Brazil. Renewable Energy 2010;35:2705-2713.

[31] Djamai M, Merzouk NK. Wind farm feasibility study and site selection in Adrar, Algeria. Energy Procedia 2011;6: $136-142$. 
[32] https://www.w2e-rostock.de/take-a-license/turbine-technologies/licensing-of-wind-turbines-with-20-mw/

[33] http://www.foerdewindwerk.delenglish/fw-2000/

[34] https://www.senvion.com/global/en/products-services/wind-turbines/mm/

[35] Mathew S, Lim CM, Petra MI, Philip GS, Noorfathin M, Mathew MS, Raj V. Matching the characteristics of low speed turbines with candidate wind regimes. Energy Procedia 2016;95:286-293.

[36] Sedaghat A, Alkhatib F, Eilaghi A, Sabati M, Borvayeh L, Mostafaeipour A. A new strategy for wind turbine selection using optimization bed on rated wind speed. Energy Procedia 2019;160:582-589.

[37] Gaddada S, Kodicherla SPK. Wind energy potential and cost estimation of wind energy conversion systems (WECSs) for electricity generation in the eight selected locations of Tigray region (Ethiopia). Renewables: Wind, Water and Solar 2016;3:10.

[38] Dabar OA, Awalehh MO, Kirk-Davidoff D, Olauson J, Söder L, Awaleh SI. Wind resource assessment and economic analysis for electricity generation in three locations of the Republic of Djibouti. Energy 2019;185: 884 -894 .

[39] Touafio JFN, Sanda O, Malenguinza S, M'Boliguipa J, Mouangue RM. Analysis of a wind turbine project in the city of Bouar (Central African Republic). Scientific African 2020;8:e00354.

[40] Ahmed AS. Electricity generation from the first wind farm situated at Ras Ghareb, Egypt. Renewable and Sustainable Energy Reviews 2012;16:1630-1635.

[41] Mortensen NG, Youssef LG. Wind Atlas for Egypt. Measurements and Modeling 1991-2005. Roskilde: Ris $\varnothing$ National Laboratory, Roskilde, New and Renewable Energy Authority, and Egyptian Meteorological Authority, Cairo; 2005. [ISBN 87-550-3493-4].

[42] New and Renewable Energy Authority, April 2015. Egypt. Annual Report. Available at: http://www.nrea.gov.eg/. 


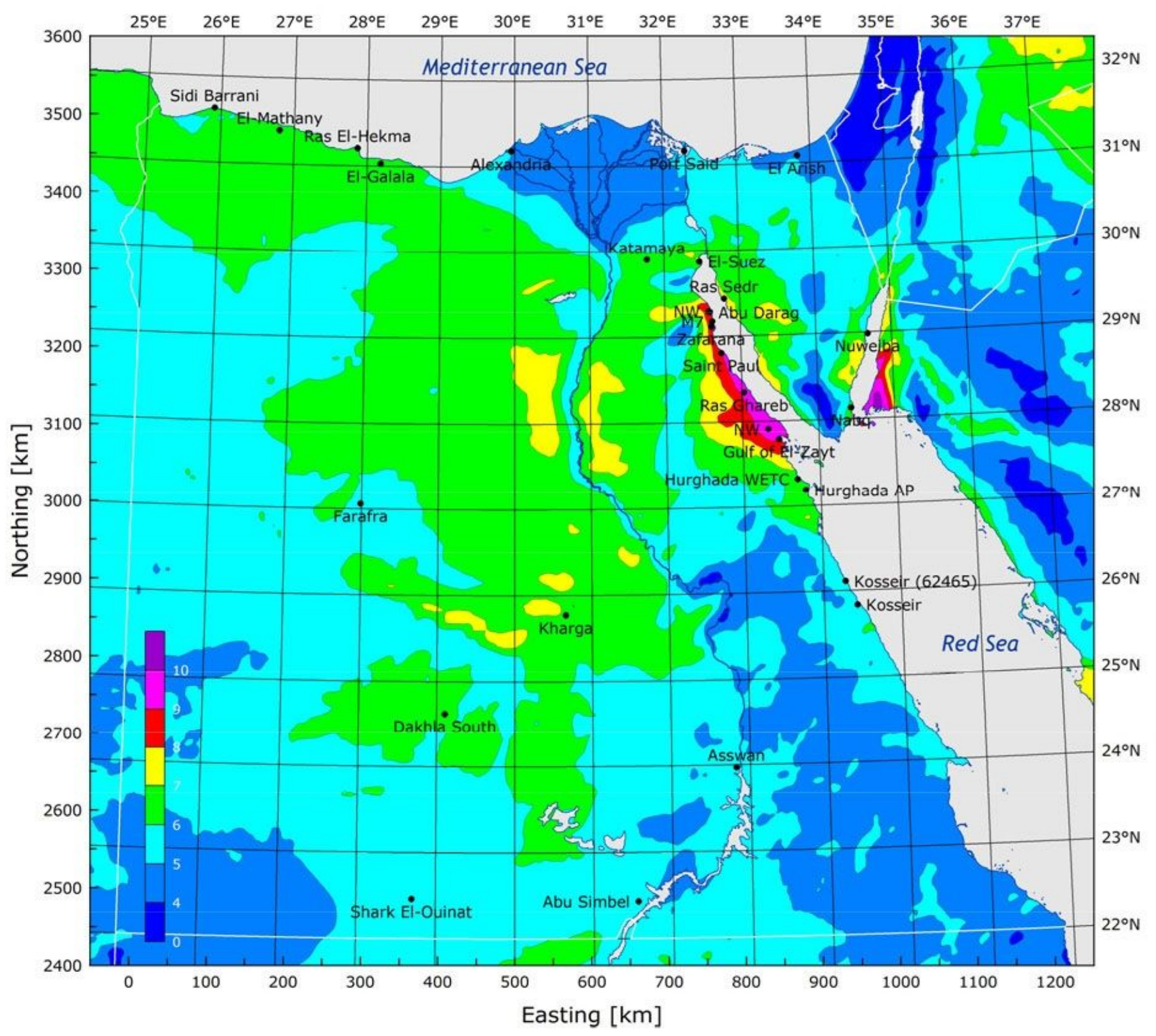

\section{Figure 1}

Location of Sidi Barrani meteorological station along Mediterranean Sea in Egypt. (Source: New wind resource map of Egypt at a height of $50 \mathrm{~m}$ over the actual land surface [41]) 


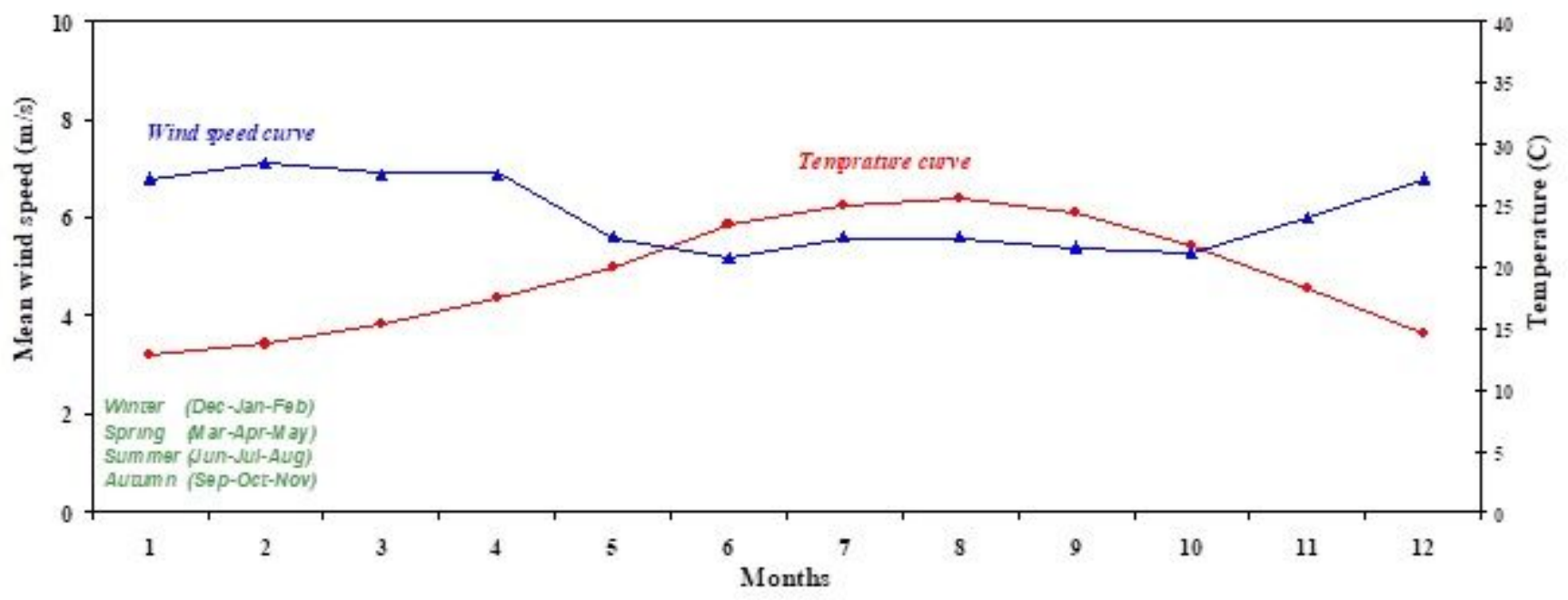

Figure 2

Variation of mean wind speed and air temperature recorded per month for Sidi Barrani station. 


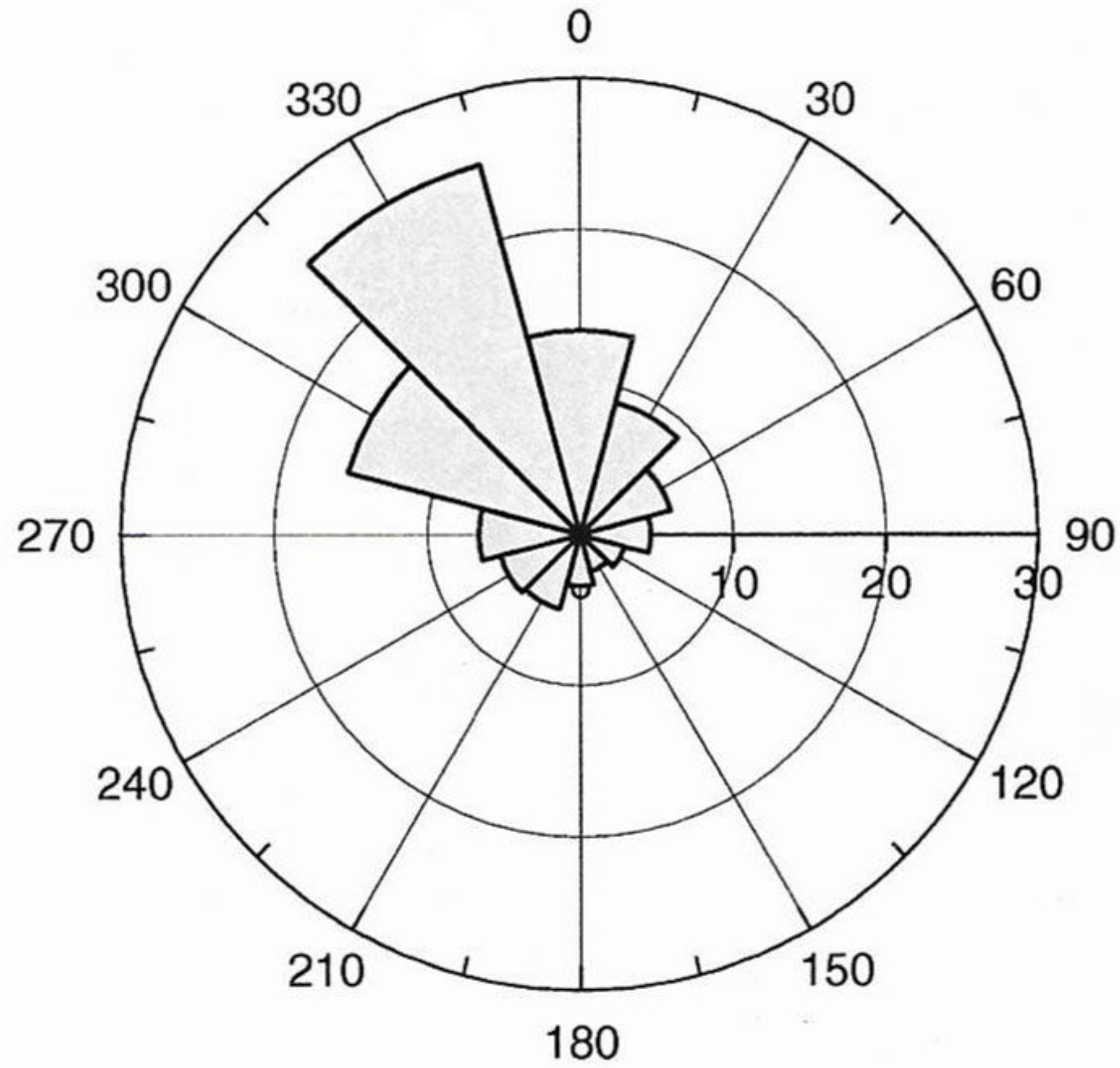

Figure 3

Yearly wind rose diagram for studied location at $10 \mathrm{~m}$ height. 


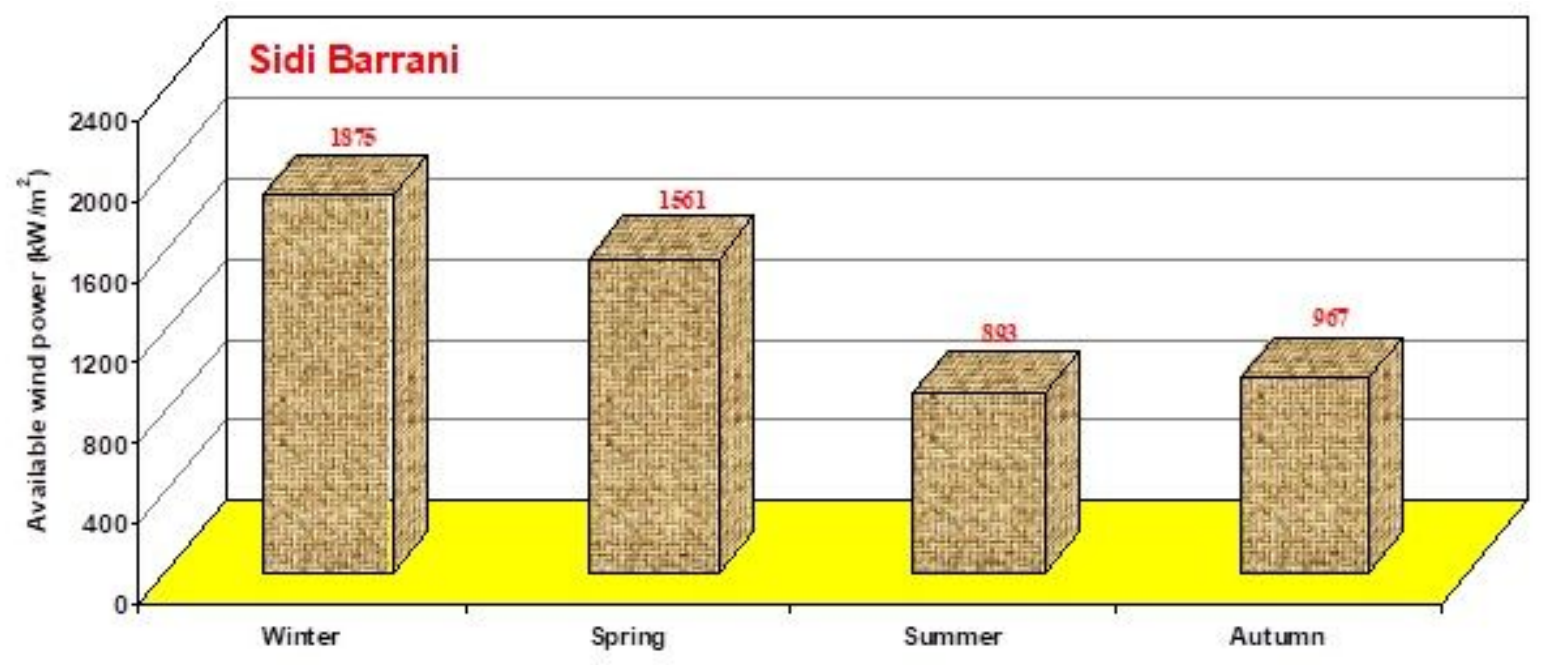

\section{Figure 4}

Seasonally values of wind power potential for hub height of $100 \mathrm{~m}$.

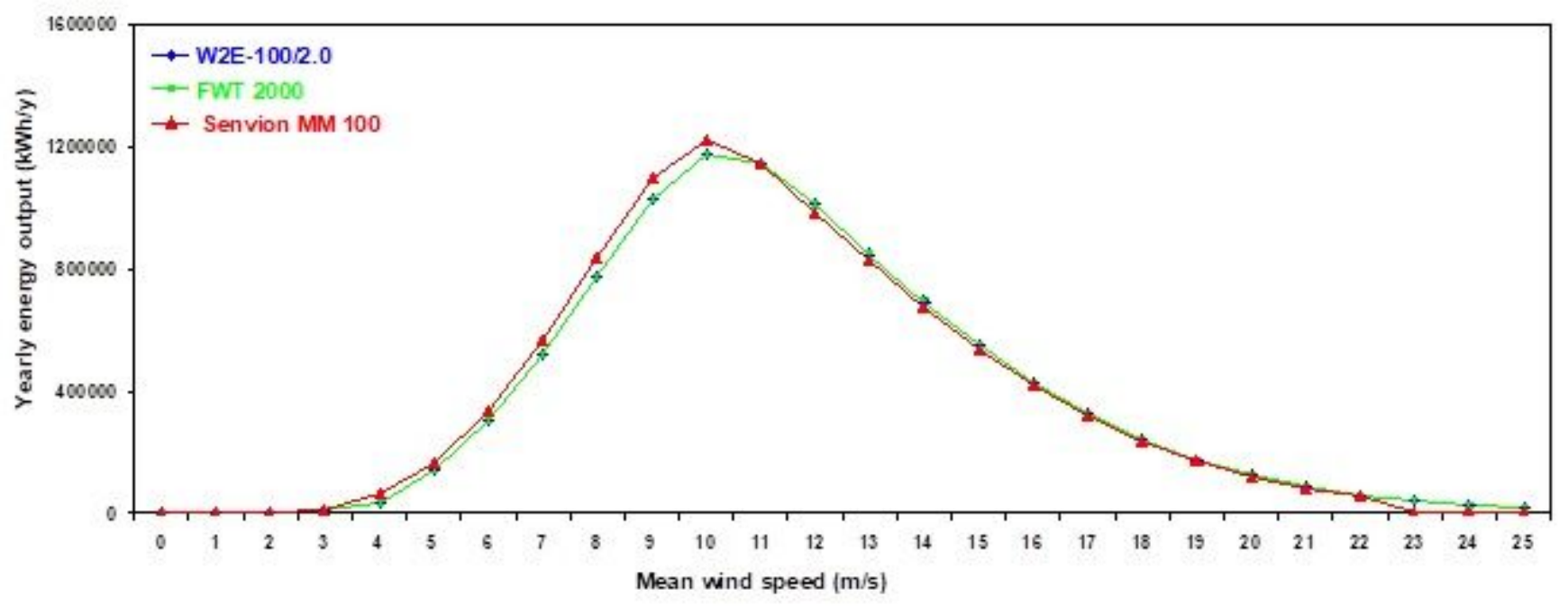

Figure 5

The average annual energy yield by three various wind turbines considered at the selected area. 